\title{
6. From Kunnanj, Fish Creek, to Mumeka, Mann River: Hunter- gatherer tradition and transformation in Western Arnhem Land, 1948-2009
}

\author{
Jon Altman
}

\section{Introduction}

Research undertaken along Fish Creek in 1948 has provided a baseline for an unusual long-term data set on utilisation of wildlife across Western Arnhem Land in the tropical savanna by people who speak a number of commonly understood dialects across the regional pan-dialectical language Bininj Gunwok. ${ }^{1}$ The title of this chapter refers to two camping localities on fresh waterways in this region. The first, Kunnanj, is on Fish Creek about $20 \mathrm{~km}$ north-east of Gunbalanya (formerly Oenpelli); the second is at Mumeka on the Mann River some $50 \mathrm{~km}$ south-west of Maningrida. The two places are about $100 \mathrm{~km}$ apart.

In October 1948, Margaret McArthur and Frederick McCarthy resided at Kunnanj with a small group of Aboriginal people from Western Arnhem Land and carefully recorded their economic activity and food consumption over 14 days. The people they camped with were not the landowners of that place; they had migrated to the Gunbalanya region from further east. ${ }^{2}$ But for the first time in Australia, Western scientific quantification and participantobservation techniques were used to record an Aboriginal group's foodgathering activities, the time spent in the food quest and patterns and levels

\footnotetext{
1 Evans, N. 2003, Bininj Gun-Wok: A pan dialectical grammar of Mayali, Kuninjku and Kune, Pacific Linguistics 541, Research School of Pacific and Asian Studies, The Australian National University, Canberra. Evans identifies six dialects in the Bininj Gunwok dialect chain. The two key dialects referred to in this chapter are Kunwinjku, spoken near Gunbalanya, and Kuninjku, spoken in the Mann-Liverpool rivers region. When I refer to Kunwinjku or Kuninjku people, I am referring to members of these dialect-sharing communities. 2 With the assistance of Murray Garde and Peter Cooke, I have identified these people as members of Durlmangkarr (country Kunburray), Djorrolom (Ngaldjun), Bularlhdja (Dolomyih), Bolmo (Marlkawo) and Bordoh (Ngolkwarre) clans and speakers of Gun-dedjnjenghmi and Kune Narayek dialects of Bininj Gunwok, and possibly also speakers of the neighbouring Dalabon language. See map in Evans, Bininj Gun-Wok, p. xxix and Figure 1. Kunnanj is part of the estate owned by members of the Murrwan Mengerrdji clan (M. Garde, Personal communication, 29 June 2009).
} 
of consumption of naturally occurring foods. This was path-breaking research that, while highly experimental, had major consequences for our thinking about the way hunter-gatherers lived in tropical savannas during pre-colonial and colonial times. From October 1979 to November 1980-some 30 years later-I resided at Mumeka outstation and undertook research on a less experimental basis during a period that was arguably post-colonial. In the subsequent 30 years, I have returned to this region regularly and continued working with speakers of the Kuninjku dialect residing at the eastern end of the Bininj Gunwok region (see Figure 6.1).

This chapter focuses on Western Arnhem Land because a continuity of research in this region over a 60-year period provides an unusual opportunity for comparative observations over time with people who share a linked linguistic, ceremonial and cultural identity. I begin by outlining the research undertaken by McArthur and McCarthy at Fish Creek on hunter-gatherer economic life. I discuss the wider implications for anthropological thinking about human evolution, gender and environmental relations of this research, especially in its broader theoretical framing by Marshall Sahlins in Stone Age Economics in 1972. I then briefly outline some findings from my own work in 1979-80 and again in 2002-03 on similar issues, before discussing continuity and change in wildlife harvesting over the past 60 years. In this discussion, I engage critically with Sahlins' interpretation of the data from Fish Creek and his more recent views on the resilience of non-capitalist indigenous economies in the highly globalised twenty-first century.

Identifying key moments of epochal change is never easy. Arguably, the immediate postwar period was such a moment of transition when nomadic hunter-gatherers in Western Arnhem Land were increasingly centralisingfirst at the mission at Gunbalanya, or Oenpelli as it was then known, and later at the trading post established at Maningrida for a year in 1949. (Maningrida was formally established as a government settlement in 1957.) In 1948, the outstations movement of the early 1970s could not have been foreseen. Today, there are many people who live on their ancestral lands, but in a different way to that observed by the Expedition. Now they are again subject to policy pressures to centralise. The chapter ends by reflecting on some of the intended and unintended legacies and lessons to be taken from the path-breaking work of McArthur and McCarthy in 1948. 


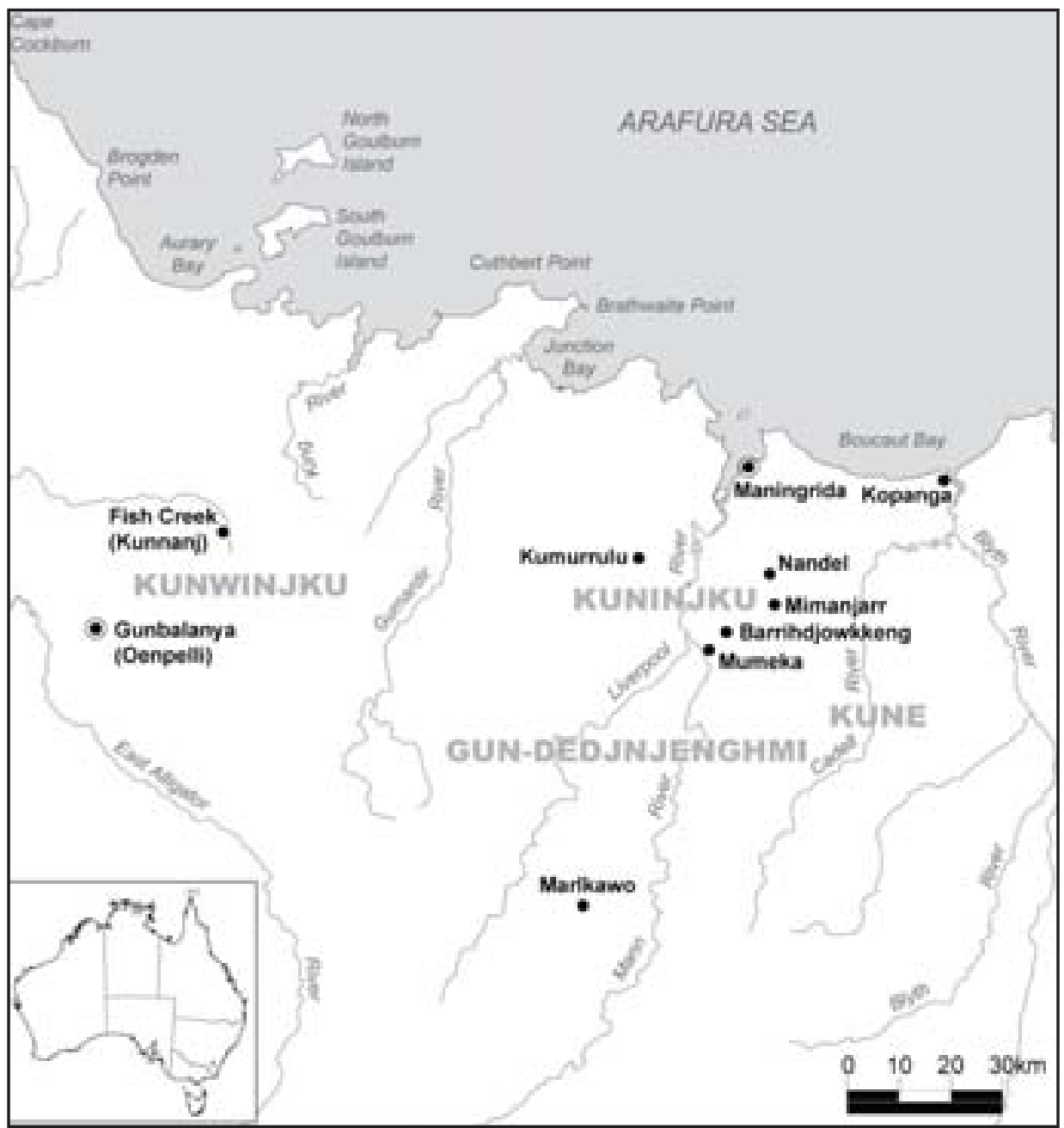

Figure 6.1 Map showing approximate distribution of the Bininj Gunwok language

\section{The Customary Economy at Kunnanj, Fish Creek, 1948}

Martin Thomas outlines the ambitious nine-point agenda for the 1948 Arnhem Land Expedition that included: to study and record Aboriginal patterns of life in relation to terrestrial and marine resources; to examine food consumption to see how well people could live off the land; to undertake a nutritional health survey; and to determine the food resources of the land and the sea. ${ }^{3}$ Much of

3 Thomas, M. 2010, 'A short history of the 1948 Arnhem Land Expedition', Aboriginal History, vol. 34. See also Lamshed, M. 1972, Monty: The biography of C. P. Mountford, Rigby, Adelaide, pp. 143-4. 
this research was left to the Nutrition Unit's Margaret McArthur-at that time a young nutritionist working at the Australian Institute of Anatomy and with a background in biochemistry and bacteriology. ${ }^{4}$

A little needs to be said about McArthur because she was quite a remarkable figure. Among the Expedition's official membership of 17, she was the sole woman scientist. Charles Mountford's wife, Bessie, the only other female on the Expedition, worked in the role of 'honorary secretary'. ${ }^{5}$ McArthur was then twenty-nine years old and had already undertaken fieldwork in New Guinea, where she had studied the diet and health of native groups. Her role was to focus on food gathering - an activity assumed to be undertaken predominantly by women. Even at that time, there was emerging recognition that since such activity was highly gendered, data collection might be affected by the gender of the researcher.

The research on food resources was published as an eight-section 'Report of the Nutrition Unit', edited by McArthur in Volume 2 of the Records of the AmericanAustralian Scientific Expedition to Arnhem Land(1960). ${ }^{6}$ The volume also contains a separate, but linked, chapter titled 'The food quest and the time factor in Aboriginal economic life', co-authored by McArthur and Frederick McCarthy, who was Curator of Anthropology at the Australian Museum. ${ }^{7}$ Interestingly, McCarthy was a material culture specialist and the direct ethnographic work he undertook at Fish Creek with McArthur was uncharacteristic of his overall career.

As McArthur explains in her introduction, the Nutrition Unit worked at three settlements: Yirrkala in North-East Arnhem Land, Umbakumba on Groote Eylandt and Oenpelli (now Gunbalanya) in Western Arnhem Land. ${ }^{8}$ Each of these localities had experienced a degree of external impact heavily mediated by the passage of the Aboriginals Ordinance in 1918 that restricted unregulated entry onto reserved lands, and the declaration of the Arnhem Land Reserve in 1931. McArthur notes, however, that these were hardly pristine pre-colonial circumstances. Aboriginal people were largely centralised at state-supported settlements where the majority participated in Western forms of work.

4 De Lepervanche, M. 2002, 'Obituary: Annie Margaret McArthur 1919-2002', The Australian Journal of Anthropology, vol. 13, no. 22, pp. 230-1.

5 Thomas, 'A short history of the 1948 Arnhem Land Expedition'.

6 I focus here on just three sections of this report: McArthur, M. 1960, 'Introduction', in C. P. Mountford (ed.), Records of the American-Australian Scientific Expedition to Arnhem Land. Volume 2: Anthropology and nutrition, Melbourne University Press, Carlton, Vic., pp. 1-13; McArthur, M. 1960, 'Food consumption and dietary levels of groups of Aborigines living on naturally-occurring foods', in ibid., pp. 90-135; and Anon. 1960, 'Conclusions and recommendations', in ibid., pp. 139-43.

7 McCarthy, F. D. and McArthur, M. 1960, 'The food quest and the time factor in Aboriginal economic life', in Mountford, Records of the American-Australian Scientific Expedition to Arnhem Land, vol. 2, pp. 145-94.

8 McArthur, 'Introduction', pp. 1-13. 
She notes that in Western Arnhem Land, white contact dated back more than 50 years (prior to 1948) to the late nineteenth century, when buffalo shooter Paddy Cahill began operating in the region. Cahill set up his residence at Oenpelli in 1906, established a farm, and employed Aboriginal labour in his buffalo and farming operations. In 1915, Oenpelli was chosen as the site for an experimental dairy farm that subsequently closed when exports of butter were boycotted by Darwin unionists because of production by black labour. ${ }^{9}$ In 1925 , the Anglican-run Church Missionary Society established a mission at Oenpelli on the western extremity of the Arnhem Land Reserve. The Expedition was based at Oenpelli in September and October 1948. Importantly, there was also a significant population east of Oenpelli, who were still living in a fundamentally pre-colonial manner, despite sporadic external contact during the war years. ${ }^{10}$ Arguably, the Arnhem Land Expedition should have gone further east.

The research that I focus on here reported on two aspects of Aboriginal economic life: the quantity of naturally occurring foods consumed by a group of nine adults camped at Kunnanj, from where they walked to hunt, fish and gather in the immediate area (see Figure 6.1); and the time these people spent on food collection in relation to all other activities. This was unusual research on two counts. First, McArthur, assisted by McCarthy, John Bray (Expedition cook and honorary entomologist) and two local interpreters, identified only as Joshua and Dorcas, directly observed and recorded all activities over 14 days, although food consumption was reported for 11 days only. ${ }^{11}$ Second, the participants were asked to participate in the research on an experimental basis so they were required not to consume any Western foods to which they had limited access via the mission. ${ }^{12}$ Although the Fish Creek group was the only inland group studied, it was the one scrutinised in greatest detail. The observations were probably more streamlined than at coastal Hemple Bay, where a similar exercise had been undertaken with a slightly larger, but more dispersed, group over seven days in May 1948.

9 Clinch, M. A., 1979, 'Cahill, Patrick (Paddy) (1863?-1923)', Australian Dictionary of Biography. Volume 7, Melbourne University Press, Carlton, Vic., pp. 521-2.

10 G. Sweeney, 1939, Report of patrol in the Junction Bay, Liverpool River and Tomkinson River areas, JulyAugust 1939, Typescript, Australian Archives File 64/2231; Kyle-Little, S. 1957, Whispering Wind, Adventures in Arnhem Land, Hutchinson, London.

11 It is noteworthy that McCarthy and McArthur do not mention three other Aboriginal people who were at Fish Creek. For the entire time, Mary, the seven-year-old daughter of Joshua and Dorcas, was at Fish Creek, while for the first four days two other people, Wendy and Jerrimin-min, also accompanied the interpreters, mainly it seems to act as social mediators with the group that was unfamiliar with Joshua and Dorcas. There could have also been other Aboriginal visitors to Fish Creek. This information has come to light only recently in the diary of Expedition cook, John E. Bray (Arnhem Land Expedition 1948: private journal, Private collection of Andrew Bray, pp. 170, 174). Interestingly, I interacted with the same (now deceased) Jerry Jerrimin-min in 1979 and 1980 when he resided at Kurrhkurr (Table Hill) outstation on his Marin estate. 12 At one point, on 12 October 1948, two of the Aboriginal men at Fish Creek walked nearly $20 \mathrm{~km}$ to Oenpelli and back so as to access flour and rice. On their return, they were requested to refrain from consuming these foods until 21 October (McCarthy and McArthur, 'The time factor in Aboriginal economic life', p. 147). 
The nature of the interactions between the observers and the observed is only sketchily outlined in McCarthy and McArthur's paper, but indicates that in the interests of science the researchers did not share their own food with the subjects of observation and vice versa during the experimental period. McCarthy and McArthur note that they did not question the subjects of the research about their motivations or choice of activity. ${ }^{13}$ This was justified as an attempt to be as rigorous as possible and might be regarded as a little unusual today.

The direct form of observation, participation and quantification was extraordinarily innovative for that time. This was especially the case for the time-allocation study, but unfortunately no explanation is provided for its undertaking (by a nutritionist and an archaeologist) except to note that no quantitative measure of time had previously been collected in Australia on hunter-gatherer work effort, so the chance to pioneer in science might have been the motivation. McCarthy and McArthur note that the absence of timeallocation studies was a global shortcoming, referring to an article by Adrian Digby published after they had completed their fieldwork that makes this point. ${ }^{14}$

The results of the research can be summarised as follows. In her report on consumption of naturally occurring foods, McArthur carefully records the species utilised (including botanical genus and local names) and the weights of food consumed. At Fish Creek, this amounted to a total of $28 \mathrm{lbs}(12.7 \mathrm{~kg})$ of vegetables, $5.5 \mathrm{lbs}(2.5 \mathrm{~kg}$ ) of fruit, $7.5 \mathrm{lbs}(3.4 \mathrm{~kg})$ of honey, $116.5 \mathrm{lbs}(53 \mathrm{~kg})$ of fish, $360 \mathrm{lbs}(163 \mathrm{~kg}$ ) of macropod and $16.5 \mathrm{lbs}(7.5 \mathrm{~kg})$ of offal - a total of $534 \mathrm{lbs}$ of food or just on $243 \mathrm{~kg}$ at the average rate of nearly $2 \mathrm{~kg}$ per capita per day. McArthur then carefully converts all this to mean daily consumption of nutrients, taking into account the participants' gender, weight and activity levels. She found that at Fish Creek mean daily consumption was protein and calcium rich (at 5.4 and 3.6 times the daily recommended allowances respectively). The diet studied was almost optimal in terms of calories, but surprisingly (given meat-consumption levels) deficient in iron (0.3 times) and ascorbic acid ( 0.5 times). Overall, she notes, 'the diets which were seen at the four camps in Arnhem Land were well balanced and they provided amounts of most nutrients comparable with the recommended daily allowances' ${ }^{15}$ The application of such comparative measures to 'native populations' says something about the Expedition's commitment to a rigorously scientific approach.

13 McCarthy and McArthur, 'The time factor in Aboriginal economic life', pp. 146, 191.

14 Ibid., p. 145; Digby, A. 1949, 'Technique and the time factor in relation to economic organization', Man, no. 12, pp. 16-18.

15 McArthur, ‘Food consumption and dietary levels of groups of Aborigines living on naturally-occurring foods'. 
The results of the research on work effort were reported in the stand-alone chapter co-authored with McCarthy. This chapter provides important genealogical information about people at Fish Creek, a careful diary of all activities, some information on the sharing of large game, and then a summary of time occupied in various activities for all members of the group distinguished by gender. At Fish Creek, men worked an average three hours and 50 minutes per day and women three hours and 44 minutes per day in the food quest, or about 27 hours per week. At Hemple Bay, the work effort was somewhat higher at five hours and seven minutes per day for men and five hours and nine minutes for women, or about 36 hours per week.

Their analysis of these data is heavily and very properly qualified. They note that in evaluating their results, the presence of researchers and interpreters, the lower pressure on resources (owing to fewer people living in the bush), seasonality, and the unusual demographic composition of the group must all be considered. ${ }^{16}$ They also note that women's work effort in the production of utilitarian artefacts (such as mats, netted baskets and string bags) had declined owing to the availability of tins and cloth from the mission. ${ }^{17}$ They emphasise that it is hard to tell how typical their groups might be, for nearly all participants had mission or other external contact, although people did return to bush living intermittently at that time, owing to lack of food at missions or because they were seeking refuge from social or political disputes in the larger settlements. But they emphasise that their findings are valid for the groups that they actually studied, which, given their thoughtful qualifications, seems indisputable.

Some of their interesting findings are that returns from hunting especially are linked to individual ability, with hunters possessing impressive stalking skills when targeting kangaroos and dexterity in using spears and spear-throwers. Much of their emphasis is on gender differences: women fished or gathered every day, while men hunted less regularly, on every second day. This might have been linked to the issue of 'work density' (how hard people actually worked), since the observations at Fish Creek were undertaken during the hottest late dry season (kurrung). McArthur and McCarthy note that men's daily activity, especially the hunting of macropods, is apt to cause fatigue, mainly because of effort expended in stalking, chasing and then carrying heavy game back to camp. They also note the role of luck in men's hunting of mobile game compared with the greater predictability of women's harvesting of stationary plant foods. Detailed information is also provided on the rules for sharing game to meet kinship obligations.

16 McCarthy and McArthur, 'The time factor in Aboriginal economic life', p. 146.

17 Ibid., p. 193. 
McCarthy and McArthur reveal the gendered nature of work patterns, but they highlight the small difference in work effort between the sexes. They note: 'This study illustrates well the perfect co-operation that exists between the men and women in their economic life. ${ }^{18}$ This was a theme picked up by Colin Simpson in a chapter, 'Margaret sees no slaves', in his book Adam in Ochre. ${ }^{19}$ Overall, though, McCarthy and McArthur were cautious with their findings, suggesting that a 'survey of a group throughout the year on the lines of the present study would throw a great deal of light on the economic life of the men and women, and upon the theoretical problems involved in the two patterns and their relationship' ${ }^{20}$

This path-breaking research was hardly used within Australia for a long time, in part because there was a delay of 12 years between data collection and publication. But even after its publication in 1960, this research was largely ignored. For example, in their 1970 book about Kunwinjku people, Ronald and Catherine Berndt make only fleeting reference to botanical names for species listed by Margaret McArthur and no reference to her work on the time factor. ${ }^{21}$ Such disregard and lack of interest reflected antipathy within the Australian anthropological establishment of the time, especially on the part of A. P. Elkin (a powerful patron of the Berndts), who regarded Mountford as an unscientific amateur. ${ }^{22}$ McArthur's work was tarred by association. Somewhat ironically, after her work as a nutritionist in Arnhem Land and clearly inspired by participant observation, she retrained as a social anthropologist and, in 1965, was the first woman appointed to a tenured post in the Department of Anthropology at the University of Sydney, where Elkin had reigned supreme in earlier decades. ${ }^{23}$

So it came to pass that the renowned American anthropologist Marshall Sahlins, working outside the Australian scene, was the first to recognise the enormous value of this Arnhem Land research and he used the work effort and foodstuff consumption data as the factual cornerstone for his now famous proposition that hunter-gatherers were 'the original affluent society' ${ }^{24}$

Sahlins' important theoretical corrective was that it was evolutionary thinking rather than empirical evidence that depicted hunter-gatherers as either living on the subsistence margin or constantly engaged in the food quest. While Sahlins acknowledged that McArthur and McCarthy's data were collected

18 Ibid., p. 194

19 Simpson, C. 1951, Adam in Ochre: Inside Aboriginal Australia, Angus \& Robertson, Sydney, pp. 52-6.

20 McCarthy and McArthur, 'The time factor in Aboriginal economic life', p. 194.

21 Berndt, R. M. and Berndt, C. H. 1970, Man, Land \& Myth in North Australia: The Gunwinggu people, Ure Smith, Sydney, p. 36.

22 Gray, G. 2007, A Cautious Silence: The politics of Australian anthropology, Aboriginal Studies Press, Canberra, pp. 191-5. See also chapters by Jones and May, this volume.

23 De Lepervanche, 'Obituary'.

24 Sahlins, M. 1972, Stone Age Economics, Aldine and Atherton, Chicago, pp. 1-39. 
under artificial circumstances in colonial, rather than pristine, circumstances and with demographically unrepresentative groups, he threw caution to the wind somewhat in his interpretation - as is often the case in the nature of major theoretical correctives. Interestingly, Sahlins followed McCarthy and McArthur in noting the differences between Fish Creek and Hemple Bay, suggesting that a key distinction might have been the five young dependents who needed to be supported in the latter context. At Fish Creek, there were no recorded dependents, neither young nor old. McArthur, McCarthy and Sahlins all suggested that Fish Creek was a more inhospitable environment and that the late dry season was a less productive time in the seasonal cycle than the early dry (when the Hemple Bay fieldwork was conducted). Even so, people worked fewer hours at Fish Creek.

Most significantly, perhaps, Sahlins in his comparative analysis with industrial society failed to take into account that workforce participation rates in Arnhem Land were 100 per cent (all adults were workers), compared with the national rate at that time of a much lower 60 per cent, according to the 1947 Census of Population and Housing. ${ }^{25}$ Taking these participation rates into account, the 27 hours at Fish Creek converts to a comparative 45 hours per week and the 36 hours at Hemple Bay into 59 hours. This means work levels were comparable, if not higher, for Arnhem Landers. Interestingly, in 1947, only 28 per cent of Australia's working-age females were in the workforce (persons engaged in unpaid home duties were included under the 'inactive' population), compared with the more equitable gender distribution of work in Arnhem Land. These observations are arguably minor quibbles to Sahlins' broad corrective about how we view hunter-gatherers - a view that still holds considerable sway, even though it is hotly debated. ${ }^{26}$

Extremely surprising, however, are the unattributed recommendations that the Nutrition Unit made, drawing from these studies. ${ }^{27}$ McArthur had established that naturally occurring foods were nutritious and that people could sustain themselves adequately without excessive work effort. And yet the recommendations were assimilationist, arguing for the production of agrarian food and animal husbandry if Aborigines were to be given a good diet and greater employment at settlements rather than in the bush. This focus on Western food production and its distribution does not resonate with the descriptions of the harvesting of fresh food out bush and its distribution along kinship lines. One wonders if in making these recommendations the

25 Commonwealth Bureau of Census and Statistics 1952, 'Statisticians report', Census of the Commonwealth of Australia, 30th June 1947. Volume III, Commonwealth Bureau of Census and Statistics, Canberra.

26 Kaplan, D. 2000, 'The darker side of the "original affluent society"', Journal of Anthropological Research, vol. 56, no. 3, pp. 301-24. Interestingly, the issue of labour-force participation that I raise here has often been overlooked in efforts to debunk or dilute Sahlins' corrective.

27 Anon., 'Conclusions and recommendations', pp. 139-43. 
Nutrition Unit was politically influenced by the emerging postwar policy focus on the inevitability of assimilation and whether there was interference in interpretation by the Institute of Anatomy in Canberra. While McArthur edited the 'Report of the Nutrition Unit', she clearly did not want to take ownership of the recommendations, unless the absence of authorship is just a typographical error-something that I doubt. Certainly, these recommendations indicate that reliance on bush food had no future in the mind of the bureaucracy, and were based on casual observations from the missions rather than scientific quantification from the bush camps. ${ }^{28}$ Such is the political nature of knowledge production and policy recommendations.

\section{The Hybrid Economy at Mumeka, Mann River, 1979-1980}

In 1979 and 1980, I lived with a group of Kuninjku speakers whose home locality was Mumeka outstation on the Mann River. ${ }^{29}$ I was undertaking research on the structure and functioning of the contemporary Kuninjku economy. My background was in economics, but I was in the process of training to be an anthropologist. In this research, my principal residence was at Mumeka, but I accompanied people from the outstation when they moved elsewhere to seasonal camps or ceremonies. During a year-long seasonal cycle, I resided at 15 locations in addition to Mumeka. My research methods included the gathering of quantitative information on productive activity in the three sectors of the local economy. At the time, I termed them 'subsistence or non-market', 'arts and crafts', and 'social security'. I now term them 'customary', 'market' and 'state sectors' of the hybrid economy. ${ }^{30}$ Quantitative data were collected in a number of ways: by taking a daily population count; by recording work effort using time-allocation techniques; by recording all hunting, fishing and gathering returns and arts and crafts produced mainly for sale; and by recording all income received. ${ }^{31}$

The group I resided with at Mumeka outstation had a prolonged and chequered encounter with the colonial state. Located deep in Western Arnhem Land, they had experienced a less intense contact with missionaries, the state and

\footnotetext{
28 Further archival research is clearly needed to seriously test this possibility. It is important to note though that by the time this research was published in 1960, assimilation had been Commonwealth policy for nine years.

29 On Kurulk clan estate and with others mainly from Kardbam and Dangkorlo patri-clans.

30 Altman, J. 2005, 'Development options on Aboriginal land: sustainable Indigenous hybrid economies in the twenty-first century', in L. Taylor, G. K. Ward, G. Henderson, R. Davis and L. A. Wallis (eds), The Power of Knowledge, The Resonance of Tradition, Aboriginal Studies Press, Canberra, pp. 34-48.

31 Altman, J. 1987, Hunter-Gatherers Today: An Aboriginal economy in north Australia, Australian Institute of Aboriginal Studies, Canberra.
} 
the market, although many had lived at Gunbalanya in the postwar period. In 1979, there were many who knew the people who had worked with McArthur and McCarthy at Fish Creek 30 years earlier. In the 1940s and 1950s, many people continued to live in the Liverpool-Mann-Tomkinson rivers region, as indicated by surveys undertaken on foot by government patrol officers. From 1957, Kuninjku people increasingly moved to live at the government settlement established at Maningrida - a process hastened in 1963 by the blazing of a vehicular track through the savanna woodlands by a patrol from the Welfare Branch of the Northern Territory Administration. ${ }^{32}$

After a desperately unsuccessful decade of living in Maningrida, where Kuninjku people failed to adapt to the state project of improvement predicated on centralisation and sedentarisation, many went back to live on their country as part of what is now termed the outstations or homelands movement. This move was associated with a different form of economy that is partially underwritten by access to state support, production of art for sale, and engagement in hunting, fishing and gathering for self-provisioning. It is noteworthy that a similar outstations movement occurred from Gunbalanya. The mission phase observed by the Arnhem Land Expedition was not as enduring as might have been assumed in 1948 .

My research was undertaken in a similar tropical savanna inland environment to Fish Creek. The people residing there are from a social network that is part of the Bininj Gunwok linguistic block, sharing kinship and ceremonial linkages. I focus here on two comparative aspects of research with that undertaken at Fish Creek. My first focus is on consumption of food and time spent in productive activity, with the proviso that my research was undertaken under everyday, not experimental, conditions with a group that contained all age grades including children and the elderly. I observed and recorded intake of all foods, from harvesting as well as purchase, and recorded all activity undertaken, in the food quest, as well as for market exchange. My dietary analysis was undertaken over 296 days and my time-allocation study over 256 days, thus covering an annual seasonal cycle. My mode of participant observation involved active participation in activities and sharing of food with members of the group whose economic life was being recorded.

32 Altman, J. and Hinkson, M. 2007, 'Mobility and modernity in Arnhem Land: the social universe of Kuninjku trucks', Journal of Material Culture, vol. 12, no. 2, pp. 181-203. 


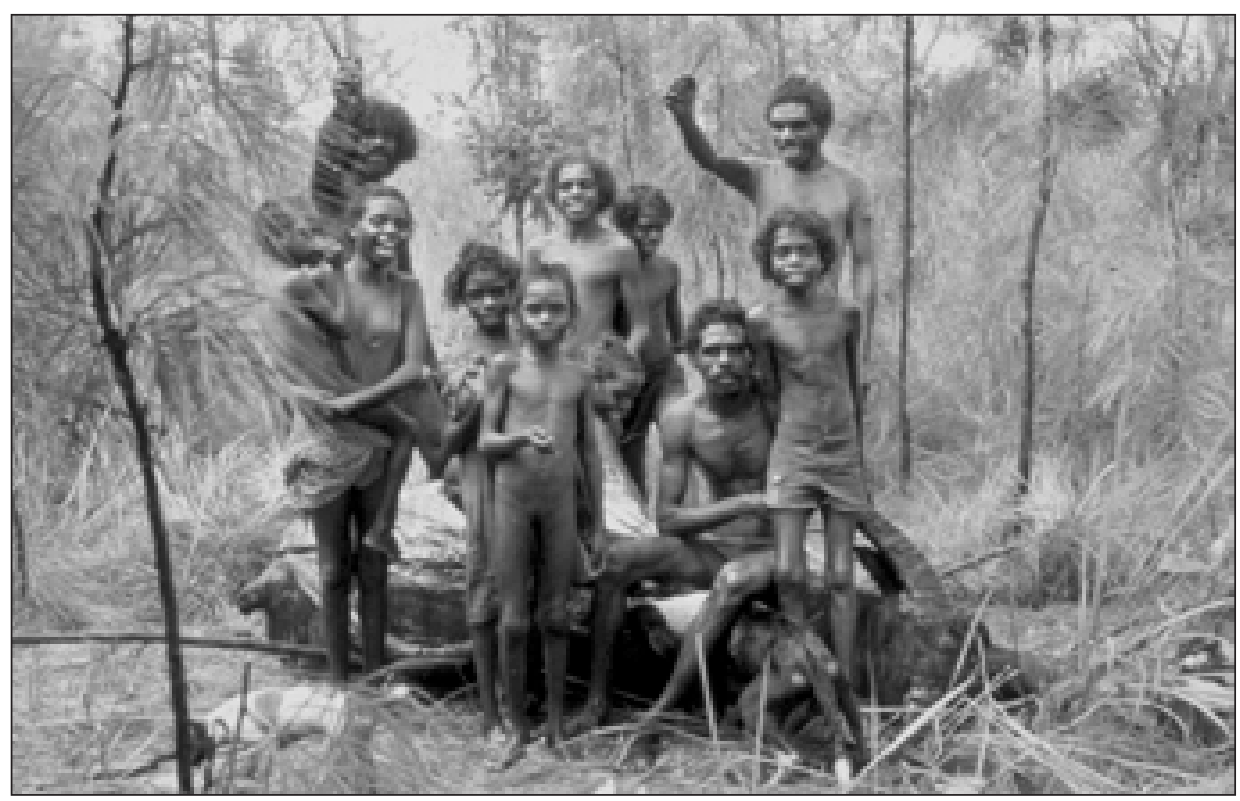

Figure 6.2 Celebrating hunting success, Barrihdjowkkeng, 1980

Photograph by Jon Altman

Using direct and indirect methods, I estimated that a total of $4777 \mathrm{~kg}$ of naturally occurring bush food was produced, with an additional $4511 \mathrm{~kg}$ of shop food purchased. In total, I estimated that just on $9288 \mathrm{~kg}$ of food was consumed by an average population of 31 people, or just on $1 \mathrm{~kg}$ per capita per day. ${ }^{33}$ Of this about half was produced, half purchased. While not a nutritionist, I, like McArthur, sought to estimate the average dietary intake for the group observed, adjusting for gender, age and weight against estimated energy and protein requirement benchmarks. Over the year, energy intake was estimated at 114 per cent of recommended requirements and protein intake at 203 per cent. Forty-six per cent of energy and 81 per cent of protein came from bush foods. ${ }^{34} \mathrm{I}$ collected information on all naturally occurring foods observed -90 faunal and 80 floral species - during my research. ${ }^{35}$

On work effort, I used a slightly different time-allocation technique and estimated that over the seasonal cycle men worked an average 3.8 hours and women 3.4

33 It is noteworthy that I estimated a net proportion of gross weight of both bush and bought foods for all varieties of food (Altman, Hunter-Gatherers Today, p. 44). Detailed data are presented in Altman, J. 1982, 'Appendix III Momega outstation: foodstuff consumption data', in Hunter gatherers and the state: the economic anthropology of the Gunwinggu of north Australia, PhD thesis, The Australian National University, Canberra, pp. 464-74.

34 Altman, Hunter-Gatherers Today, pp. 31-45.

35 Altman, J. 1983, 'The dietary utilistion of flora and fauna by contemporary hunter-gatherers at Momega outstation, north central Arnhem Land', Australian Aboriginal Studies, vol. 1984/1, pp. 35-46. 
hours per day, with a total average of 3.6 hours. Of this time, 2.6 hours were spent in the food quest, 0.8 hours in production for market exchange and 0.2 hours in miscellaneous production. Gender differences were very limited; men spent a little more time in the food quest, and women a little more time in production for market exchange. ${ }^{36}$

I make three brief comments comparing work at Fish Creek in 1948 with mine along the Mann River three decades later.

First, Margaret McArthur's nutritional survey work greatly influenced the approach taken by Betty Meehan in her research with a coastal group of Anbarra living at Kopanga outstation on the Blyth River in 1972 and 1973, as reported in her book Shell Bed to Shell Midden (1982), ${ }^{37}$ and in my later work at Mumeka. ${ }^{38}$ Using similar methods, both Meehan and I highlighted seasonal variations in the availability of bush foods, as anticipated by McArthur, with our research indicating that the wet season was the most difficult time. Meehan showed that even with access to bought foods, in January 1973 mean daily energy intake fell below recommended levels at Kopanga, while my research showed a similar sharp dip in availability of bush foods during the taxing mid wet season.

Second, at Fish Creek, McArthur found that what she termed vegetable foods made a small ( 8 per cent by weight) contribution to the diet and she suggested this was due to locational and seasonal factors. My research at Mumeka similarly found that the bush diet was made up mainly of birdlife, fish and mammals and that floral resources made a negligible contribution to the diet today, at least in terms of energy contributions (less than 5 per cent of intake from bush foods), although some species were an extremely important source of vitamins. From information collected on utilisation of floral species over the seasonal cycle, I was able to confirm McArthur's observation that the late dry season was the worst for availability of bush fruit and vegetables. ${ }^{39}$

Third, while the data on work effort were remarkably similar at just more than 25 hours per week, this figure was the average for all adults, as was the case at Fish Creek. Taking into account the 60 per cent labour force participation rate reported in the 1981 Census, it appears that Kuninjku adults at Mumeka worked just as long as other Australians - it is just that their productive work

\footnotetext{
36 Altman, Hunter-Gatherers Today, pp. 71-95.

37 Meehan, B. 1982, Shell Bed to Shell Midden, Australian Institute of Aboriginal Studies, Canberra. Meehan undertook a major study of Anbarra foraging based at the coastal outstation of Kopanga during 1972-73. Her research is of greater comparative relevance to the data collected by McArthur at coastal camps on Groote Eylandt, but that is another analysis that cannot be undertaken here.

38 This was overlooked by Raymond Specht when he suggested that McArthur's nutritional research is virtually unknown today. See Specht, R. 2002, 'Margaret McArthur Oliver', Australian Aboriginal Studies, vol. 2, pp. 122-3.

39 Altman, 'The dietary utilisation of flora and fauna by contemporary hunter-gatherers at Momega outstation, north central Arnhem Land', p. 39.
} 
effort outside the home was more evenly shared by all adults. Importantly, while gendered work effort at Fish Creek and Mumeka remained remarkably similar between 1948 and 1979-80, in the wider society there was a rapid growth in female workforce participation and a complementary decline in male workforce participation. ${ }^{40}$

The combination of these three findings led me to re-examine Sahlins' 'original affluent society' proposition. Using my data, I argued that if affluence is measured in hours worked then it is likely to be a contemporary rather than a pre-colonial condition since energy-intensive foods, which would have been gathered mainly by women, are now purchased. If workforce participation rates are also taken into account then, at a societal level, work effort outside the home appears remarkably similar for Aboriginal people in Arnhem Land and the rest of the Australian population as measured in official statistics. ${ }^{41}$

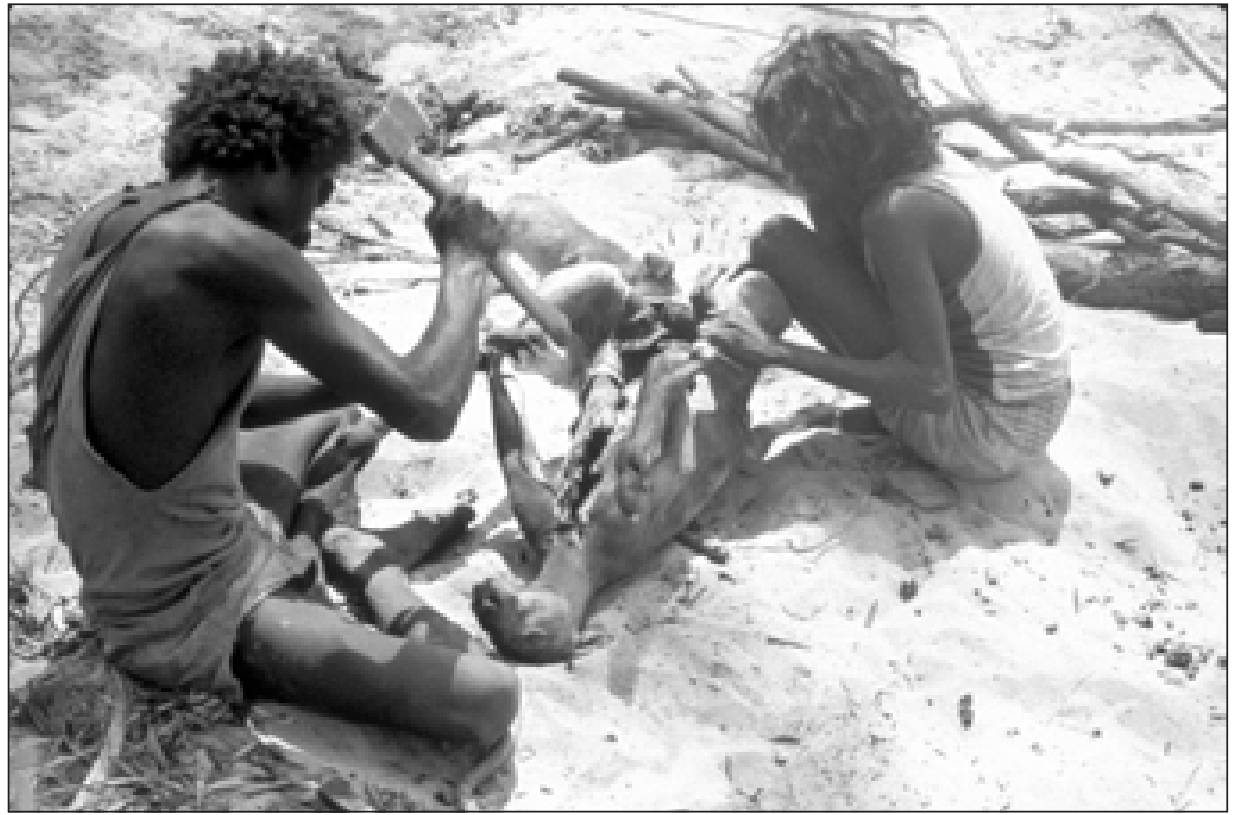

Figure 6.3 Butchering a kangaroo, Midjadukkdor, 1980

Photograph by Jon Altman

40 In the 1947 Census, 93 per cent of males of working age and 28 per cent of females were in the workforce; by the 1981 Census, these proportions had changed to 77 per cent for males and 46 per cent for females.

41 Altman, J. 1984, 'Hunter-gatherer subsistence production in Arnhem Land', Mankind, vol. 14, no. 3, pp. 179-90. In this article, I erroneously question McCarthy and McArthur's time-allocation study (at p. 185) when I am in fact taking issue with Sahlins' interpretation. 


\section{Tradition and Transformation, 1948-2009}

Clearly, a comprehensive assessment of tradition and transformation in Western Arnhem Land is beyond the scope of this brief chapter. What I want to do here is focus on just a few select elements of the regional Aboriginal economy that are amenable to some comparative analysis. This is despite the fact that today people use vehicles and guns that were not available to them at Fish Creek and have access to other market commodities. ${ }^{42}$ The material presented can be interpreted using an analytical model that I have devised to explain the contemporary hybrid economy in this part of the world. This model represents the productive economy as being made up of three interlinked sectors - the market, the state and the customary - that in combination generate cash and imputed (non-market) income. ${ }^{43}$ I use this approach to briefly outline economic continuity and change initially from 1948 to 1980 - a 30-year slice of time; and then from 1980 to the present - another slice of time of 30 years. I then look to the future.

\section{8 to $1979-80$}

In pre-colonial times, almost all production was undertaken in the customary sector, since there was no market institution or state sector, although there was some exchange whereby goods and services were traded both with Macassans and between Aboriginal groups across Arnhem Land. There is some debate in the literature about whether this trade was principally a social or an economic institution. By 1948, both the market and the state had partially penetrated Western Arnhem Land and a mission had been established at Gunbalanya to mediate and ameliorate this contact.

The survey at Fish Creek aimed to experimentally recreate the customary economy but post-colonial transformation had already occurred. The nine Aboriginal people at Fish Creek had migrated to the region from the Arnhem Land Escarpment and a number had employment experience outside Arnhem Land, mainly in the war economy. Their food-gathering equipment was influenced by post-colonial circumstances - for example, the spears used for hunting had metal heads and the digging sticks were made of iron. Nevertheless, people had clearly retained pre-colonial hunting and gathering skills, as documented by McArthur and McCarthy. All the activity they recorded at Fish Creek occurred in the customary sector.

42 For a discussion of contemporary Kuninjku use of vehicles and associated transformations, see Altman and Hinkson, 'Mobility and modernity in Arnhem Land'.

43 For discussion of the hybrid economy model, see Altman, 'Development options on Aboriginal land'. 
Thirty years later, Kuninjku people at Mumeka were among several hundred people who had returned to live at outstations. There was strong continuity in tradition, as the mainstay of the economy continued to be the customary sector. Using social-accounting methodology to give market replacement values to harvested bush foods, I estimated that the customary sector accounted for 64 per cent of the Mumeka economy. But there was also significant transformation, so that people engaged in market exchange to earn cash (10 per cent of income) and also received transfer payments from the Australian state (26 per cent of income). Cash was used to purchase Western foods as well as guns and vehicles, and outstation residents were benefiting from a limited range of services provided from the township of Maningrida and underwritten by the Australian state. ${ }^{44}$

The shift from the experimental customary economy at Fish Creek to an everyday hybrid economy at Mumeka was precipitated in part by changes in legal arrangements: in the 1970s Aboriginal people in Arnhem Land were granted land rights and citizenship entitlements to welfare, while the policy of self-determination facilitated a return to living on country. A market sector was established at outstations by the sale of arts and crafts for cash, brokered by a new government-subsidised arts-collection agency: Maningrida Arts and Crafts. But most importantly, Kuninjku people exercised agency in choosing to return to live on their ancestral lands rather than in the township of Maningrida.

\section{$1979-80$ to 2009}

Just as 1948 provided a quantitative baseline against which to measure change 30 years later, so my work at Mumeka has become historical and provides a new baseline against which to assess subsequent economic change in Western Arnhem Land. This is especially the case because information was collected over the entire annual seasonal cycle, locally divided into six seasons, and for all three broad sectors of the economy. Some updating of my work at Mumeka was undertaken nearly 20 years later, in 1996-97, by a team of biophysical scientists, although their focus was on wildlife utilisation rather than local consumption or work effort. ${ }^{45}$

In 2002 and 2003, I had the opportunity to collaborate with another team of biophysical and social scientists to survey wildlife utilisation at five localities in Kuninjku country, working with many of the same people who were at Mumeka in 1979-80. ${ }^{46}$ This research was undertaken on an experimental basis at Mumeka, Nandel, Mimanjarr, Kumurrulu and Barrihdjowkkeng in July 2002, at Mumeka in January 2003, and at Mumeka and Kumurrulu in August 2003.

\footnotetext{
44 Altman, Hunter-Gatherers Today, pp. 47-57.

45 Vardon, M. J, Gaston, S. M., Niddrie, J. and Webb, G. J. W. 1999, 'Wildlife use at Momega, north-central Arnhem Land', Australian Biologist, vol. 12, no. 1, pp. 15-22.

46 The collaborators in July 2002 were Tony Griffiths, Jennifer Koenig, Joe Morrison and Guy Pardon; in January 2003, Melinda Hinkson and Tony Griffiths; and in August 2003, Tony Griffiths and James Smith from 
Survey periods varied from 10 to 14 days, and were thus of similar duration to McArthur and McCarthy's fieldwork at Fish Creek, but now they could be matched against my earlier records from nearby localities at similar periods in the seasonal cycle some 23 years earlier.

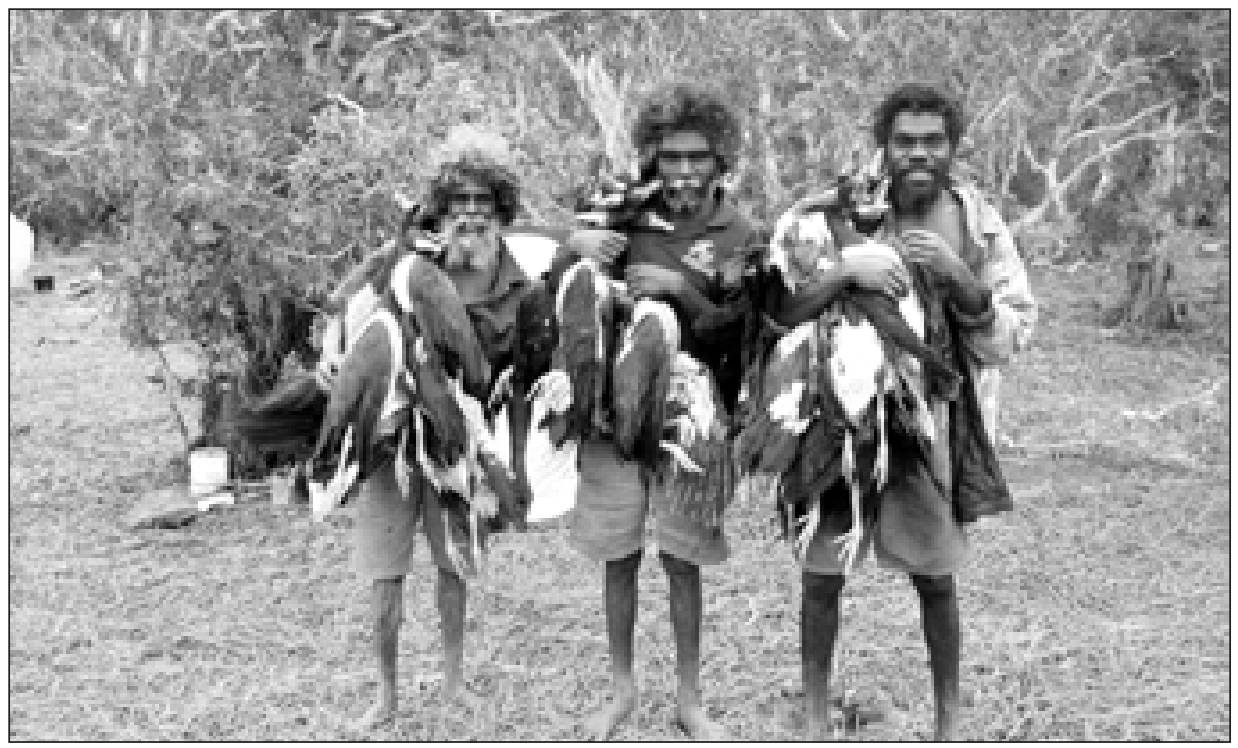

Figure 6.4 Returns from a magpie-goose hunt, Nandel, 2002

Photograph by Tony Griffiths

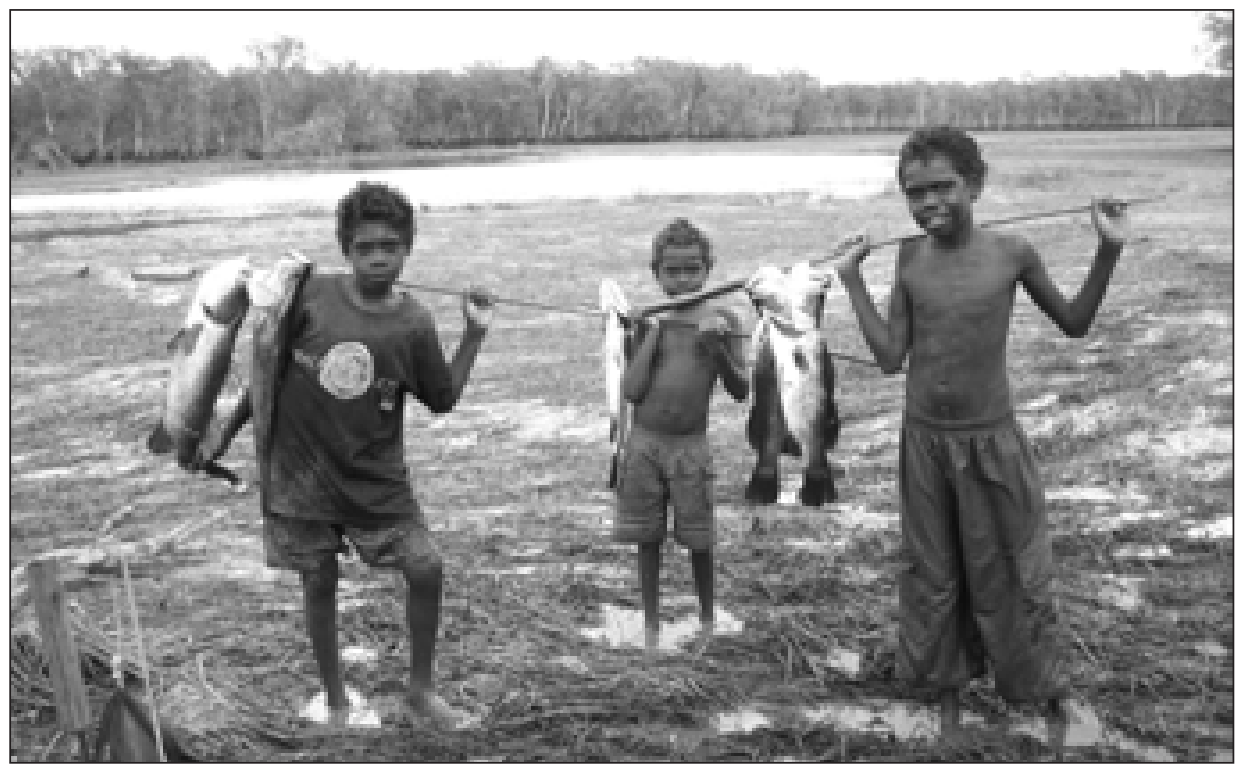

Figure 6.5 Returns from a barramundi drive, Nandel, 2002

Photograph by Tony Griffiths 
This research indicated three key continuities. First, actual wildlife harvesting practices were remarkably similar in both periods, despite the passing of more than two decades. This indicates inter-generational skills and knowledge transfer. Second, the quantum harvested was of a similar magnitude. And third, while the range of species harvested was similar, there was some decline in reptile exploitation owing to the arrival in the region of the poisonous cane toad and an increase in hunting of the feral pig - also a relatively recent arrival in the region. ${ }^{47}$

There have also been some major changes. In overall terms, using the hybrid economy framework, the significance of the customary sector had declinedin part because people were receiving more monetary income from engagement with the visual-arts sector and from payment of income under the Community Development Employment Projects (CDEP) scheme - so the market and state sectors had grown, as had the articulations between them. For Kuninjku, the greater inter-sectoral linkages were evident in more fine-art production, a greater engagement of the local with the global, and more discretionary income to purchase vehicles, which resulted in increased mobility between Maningrida township and the bush. The nature of customary engagement has also changed. It is now more variable and there is far more shortterm visitation onto country for hunting using vehicles and guns, and far more focus on harvesting particular large species such as introduced feral water buffalo, which are widely shared. The significance of bush fruit and vegetables - already limited according to earlier research at Fish Creek and at Mumeka-has declined further and is now negligible.

Another significant transformation has seen people in Western Arnhem Land engage more formally in natural resource management activities as community rangers over the past decade. In 2007, the Australian Government introduced a new program, Working on Country, that pays community rangers a proper salary rather than the more limited benefits available under the part-time CDEP scheme. People now engage in a range of activities that utilise customary knowledge integrated with Western scientific knowledge and technology to manage environmental threats as well as to abate carbon emissions by seasonally managing fire regimes at a landscape scale across Western Arnhem Land.

47 Altman, J. 2003, 'People on country, healthy landscapes and sustainable Indigenous economic futures: the Arnhem land case', The Drawing Board: An Australian review of public affairs, vol. 4, no. 2, pp. 65-82. 


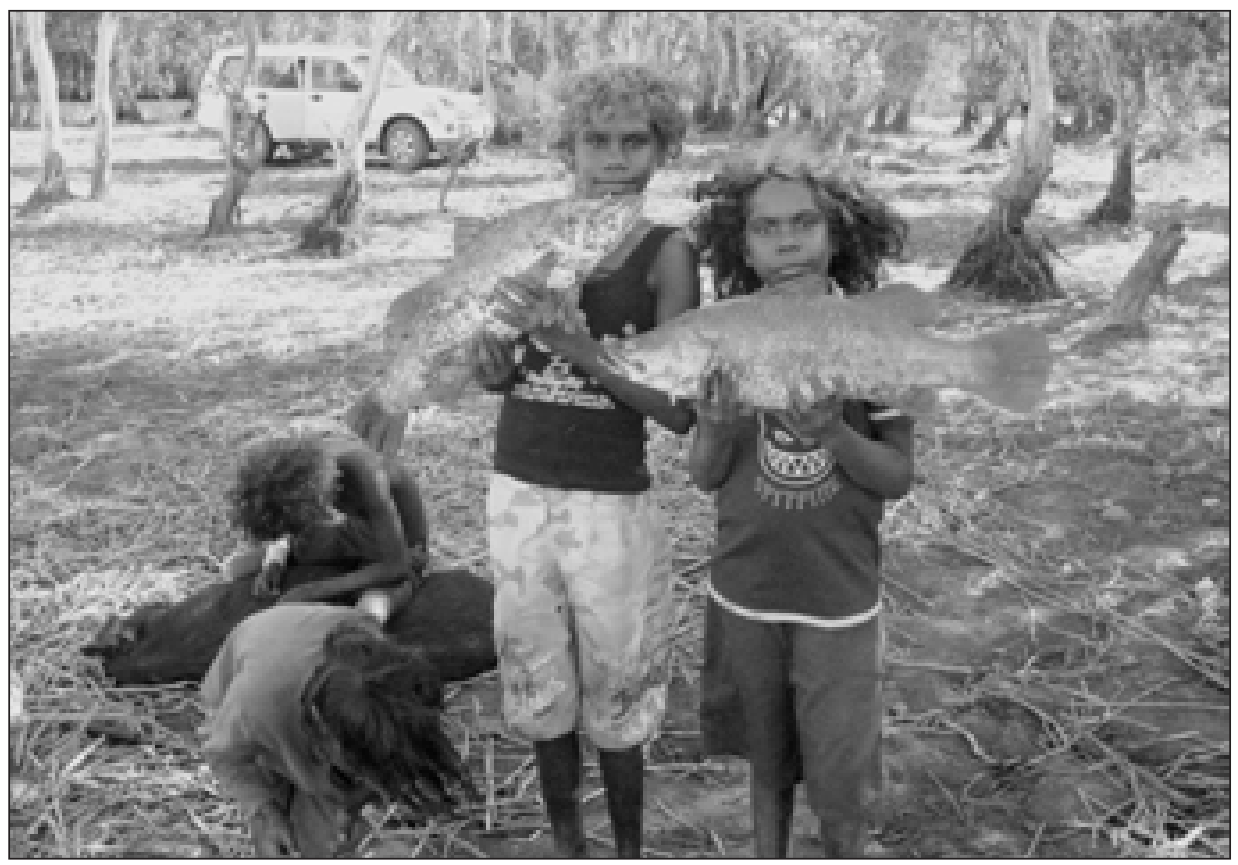

Figure 6.6 Children with barramundi and feral pig, Nandel, 2008

Photograph by Jon Altman

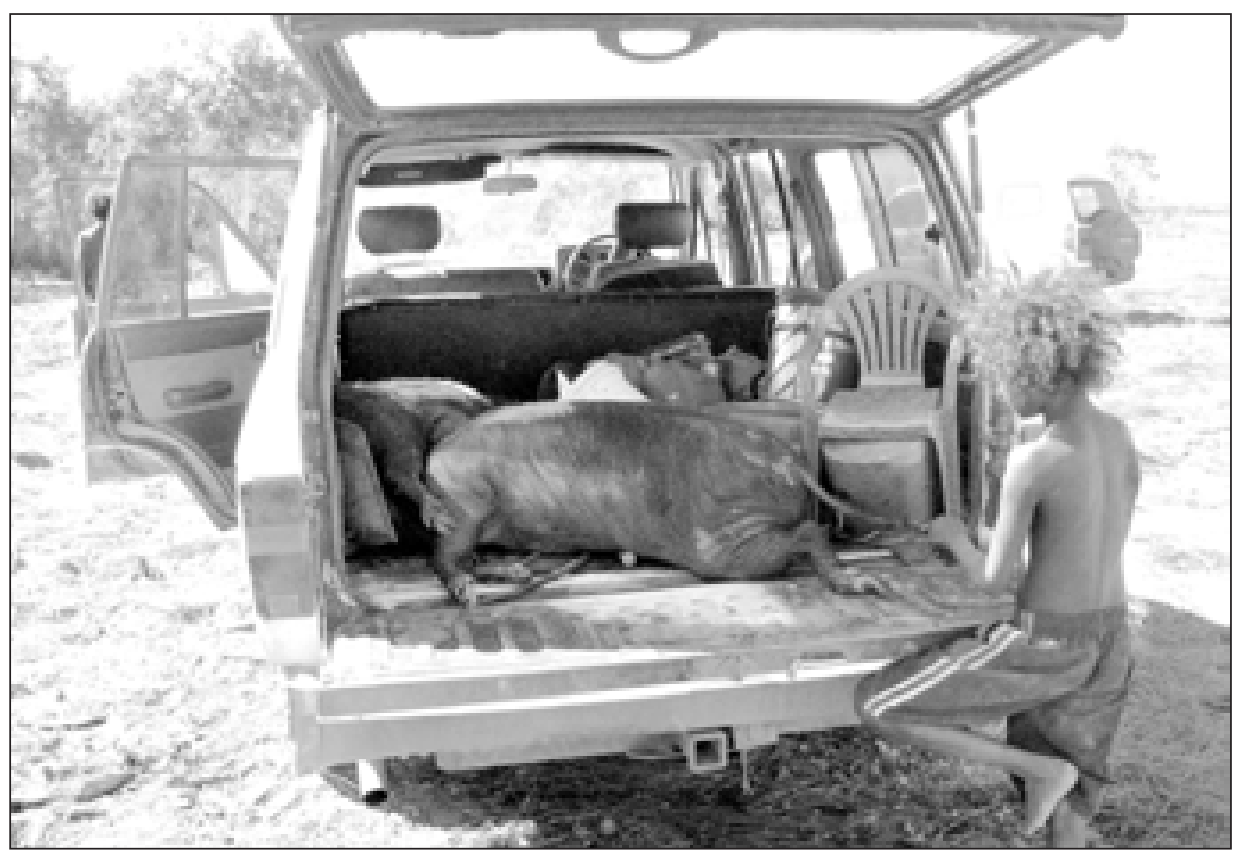

Figure 6.7 Transporting feral pig carcasses, Nandel, 2008 


\section{Hunter-Gatherers Yesterday, Today-What About Tomorrow?}

The analysis undertaken here indicates that while there have been significant regional transformations over the past 60 years, people in Western Arnhem Land still engage in hunting and gathering, ensuring that it remains of economic and cultural significance. Even though the overall significance of the customary sector has declined, it is environmentally sustainable. Part of the decline has been linked to reduced utilisation of floral species and a heightened focus on hunting and fishing, so the pre-colonial hunter-gatherers might be referred to today more accurately as hunter-fishers. The utilisation of wildlife continues in the late modernity of twenty-first-century Australia, but it is now part of a more complex hybrid economy.

It is apposite, perhaps, to frame this discussion of continuity and change within the framework proposed in a recent survey article by Marshall Sahlins, in part because it was his 'original affluent society' theory that placed Fish Creek on the world stage of scholarship. In his 1999 essay 'What is anthropological enlightenment?', Sahlins surveys recent ethnographies of indigenous modernities and finds the predictive powers of anthropology wanting. He suggests that counter to what he terms 'despondency theory', less powerful people are not destined to lose their cultural coherence. On the contrary, local indigenous societies look to organise the forces of late capitalism and the state according to their own value systems with varying degrees of success, and hunter-gatherer engagements with the global economy and modern nationstates have not fundamentally altered customary organisation of production and social and spiritual relations to nature. Rather, Sahlins refers to the indigenisation of modernity and parallel processes of global homogenisation and local differentiation. In all of this, Sahlins is not suggesting that there has been no change, but rather that despite change something distinctly indigenous remains and that 'indigeneity' has itself changed the face of modernity. ${ }^{48}$

As with his original affluent society corrective, there is something intuitively appealing about this new corrective, although again Sahlins overstates the case by overlooking the structuring force of the powerful state and market. Having looked back over 60 years at Fish Creek and then on the Mann River and seen a degree of resilience, if not triumph, of hunter-gatherers in Western Arnhem Land to date, what are the prospects for the future?

48 Sahlins, M. 1999, 'What is anthropological enlightenment? Some lessons of the twentieth century', Annual Reviews in Anthropology, vol. 28, pp. 1-23. 
Despite Sahlins' optimism based on late twentieth-century history, prospects remain especially hard to predict given the current uncertainty around climate change, which will inevitably impact on biodiversity and naturally occurring foods. The immediate challenge, however, appears to be early twenty-firstcentury despondency in Australian Indigenous affairs that is seeking to revisit the failed state project of improvement - now termed more benignly 'Closing the Gap' or normalisation - that focused on centralisation and assimilation in the 1960s, and that was rejected by those who returned to live at outstations. Despite a growing body of evidence used to contend that people living on country enjoy better health status ${ }^{49}$ and have more robust hybrid economy livelihoods than others, ${ }^{50}$ the Australian state seems committed to limiting support for outstations and abolishing flexible income-support arrangements that underpin outstation living. While there is a growing instrumental state view that Aboriginal people in Western Arnhem Land can provide environmental services in the national interest, the connection of such a provision with living on country seems to be oddly absent from policy thinking.

\section{Conclusion}

This chapter has revisited path-breaking research undertaken at Fish Creek that demonstrates the powers of quantification and participant observation in generating quantitative and qualitative data. These data showed that under experimental conditions Aboriginal people in 1948 could meet their dietary needs, consuming only naturally occurring foods with reasonably modest labour input. This has provided a baseline and broad methodological approach that remains of value today. The information collected, however, had greater theoretical than applied application: it was used by Marshall Sahlins to promote his theory of hunter-gatherers as the original affluent society. Recommendations by the Arnhem Land Expedition, based on this information and reflecting the policy environment of the time, promoted dietary improvement utilising Western foods and production techniques, rather than customary practices, which were shown to be highly effective. Some time later, Sahlins used the same data to challenge the supposed superiority of modernity over the 'stone age' - a conceit embedded in the very rationale for the Arnhem Land Expedition.

49 Burgess, C. P., Johnston, F. H., Berry, H. L., McDonnell, J., Yibarbuk, D., Gunabarra, C., Mileran, A. and Bailie, R. S. 2009, 'Healthy country, healthy people: the relationship between Indigenous health status and "caring for country"', Medical Journal of Australia, vol. 190, no. 10, pp. 567-72; Garnett, S. T., Sithole, B., Whitehead, P. J., Burgess, C. P., Johnston, F. H. and Lea, T. 2009, 'Healthy country, healthy people: policy implications of links between Indigenous human health and environmental condition in tropical Australia', The Australian Journal of Public Administration, vol. 68, no. 1, pp. 53-66.

50 Altman, 'People on country, healthy landscapes and sustainable Indigenous economic futures'. 
Since 1948 there has been significant economic transformation throughout Western Arnhem Land, but Aboriginal people remain determined to engage in customary activity and to harvest wildlife for sustenance. There is growing evidence that engaging in the customary sector generates health and livelihood benefits. This evidence base, as in 1948, appears to have little impact on policy makers, who disregard such options. The current one-dimensional fantasy for the people of Western Arnhem Land is communities re-centralised in what are now to be called 'Territory Growth Towns'. It will be interesting to see how Aboriginal people engage with this new state project of improvement and what impacts this policy shift has on a customary sector that has remained remarkably resilient in this region over the past 60 years.

\section{Acknowledgments}

I would like to thank Geoff Buchanan for research assistance, especially in locating 1947 Census material, assisting in summarising harvesting data from 2002 and 2003 and for comments; Marie de Lepervanche for her recollections in two short interviews about Margaret McArthur; Gillian Cosgrove for drawing the map; and Murray Garde and Peter Cooke for assisting in locating the country and clan affiliations of residents at Fish Creek in 1948. I would also like to thank Martin Thomas, Bill Fogarty, Melinda Hinkson, Nicolas Peterson and Murray Garde for their input, and helpful comments from anonymous refereeing. 